\title{
Interpretation of high resolution airborne magnetic data (HRAMD) of Ilesha and its environs, Southwest Nigeria, using Euler deconvolution method
}

\author{
Interpretacija visokoločljivilh aeromagnetnih podatkov (hramd) \\ območja ileshe $v$ jugozahodni nigeriji $z$ uporabo metode eulerjeve \\ dekonvolucije
}

\section{Oluwaseun Tolutope Olurin}

Department of Physics, Federal University of Agriculture, P.M.B. 2240, Abeokuta, Ogun State, Nigeria

e-mail: olurin@physics.unaab.edu.ng/stolurin@yahoo.com

\begin{abstract}
Interpretation of high resolution aeromagnetic data of Ilesha and its environs within the basement complex of the geological setting of Southwestern Nigeria was carried out in the study. The study area is delimited by geographic latitudes $7^{\circ} 30^{\prime}-8^{\circ} 00^{\prime} \mathrm{N}$ and longitudes $4^{\circ} 30^{\prime}-5^{\circ} 00^{\prime} \mathrm{E}$. This investigation was carried out using Euler deconvolution on filtered digitised total magnetic data (Sheet Number 243) to delineate geological structures within the area under consideration. The digitised airborne magnetic data acquired in 2009 were obtained from the archives of the Nigeria Geological Survey Agency (NGSA). The airborne magnetic data were filtered, processed and enhanced; the resultant data were subjected to qualitative and quantitative magnetic interpretation, geometry and depth weighting analyses across the study area using Euler deconvolution filter control file in Oasis Montag software. Total magnetic intensity distribution in the field ranged from -77.7 to $139.7 \mathrm{nT}$. Total magnetic field intensities reveal high-magnitude magnetic intensity values (high-amplitude anomaly) and magnetic low intensities (low-amplitude magnetic anomaly) in the area under consideration. The study area is characterised with high intensity correlated with lithological variation in the basement. The sharp contrast is enhanced due to the sharp contrast in magnetic intensity between the magnetic susceptibilities of the crystalline
\end{abstract}

\section{Povzetek}

V prispevku je opisana študija interpretacije visokoločljivih aeromagnetnih podatkov Ileshe in okolice $\mathrm{z}$ območja geološkega kompleksa podlage $\mathrm{v}$ jugozahodni Nigeriji. Raziskano ozemlje se razteza med zemljepisnima širinama $7^{\circ} 30^{\prime} \mathrm{N}$ in $8^{\circ} 00^{\prime} \mathrm{N}$ ter dolžinama $4^{\circ} 30^{\prime} \mathrm{E}$ in $5^{\circ} 00^{\prime} E$. Raziskavo so izvedli z uporabo Eulerjeve dekonvolucije filtriranih digitalnih meritev totalnega magnetnega polja (List št. 243) z namenom, ugotoviti geološke strukture na raziskovanem ozemlju. Digitalizirani aeromagnetni podatki, merjeni leta 2009, izvirajo iz arhiva Nigerijskega geološkega zavoda (NGSA). Aeromagnetne podatke so filtrirali, obdelali in ojačili ter nato podvrgli kvalitativni in kvantitativni magnetni interpretaciji ter geometrijskim in globinsko tehtanim analizam prek raziskovanega ozemlja $\mathrm{z}$ uporabo Eulerjevo dekonvolucijsko filtrirane kontrolne datoteke na Oasis Montagovi programski opremi. Porazdelitev totalne intenzitete magnetnega polja se giblje med -77,7 in 139,7 nT. Magnetno polje izkazuje na proučevanem ozemlju visoke vrednosti magnetne intenzivnosti (visokoamplitudne anomalije), pa tudi nizke vrednosti (nizkoamplitudne magnetne anomalije). Za ozemlje je značilna povezanost visoke intenzitete $\mathrm{z}$ veliko litološko spremenljivostjo geološke podlage. Oster kontrast nastaja zaradi velikih razlik magnetne intenzitete, ki so posledica zelo različne magnetne susceptibilnosti kristalastih in sedimentnih kamnin. Za karto, preraču-

כ Open Access. (@) 2017 Oluwaseun Tolutope Olurin, published by De Gruyter. (cc) BY-NC-ND This work is licensed under the Creative Commons Attribution-NonCommercial-NoDerivatives 4.0 License. 
and sedimentary rocks. The reduced-to-equator (RTE) map is characterised by high frequencies, short wavelengths, small size, weak intensity, sharp low amplitude and nearly irregular shaped anomalies, which may due to near-surface sources, such as shallow geologic units and cultural features. Euler deconvolution solution indicates a generally undulating basement, with a depth ranging from -500 to $1000 \mathrm{~m}$. The Euler deconvolution results show that the basement relief is generally gentle and flat, lying within the basement terrain.

Key words: aeromagnetic, anomaly, basement complex, data, Euler deconvolution, lithology nano na ekvatorsko lego, so značilne visoke frekvence, kratke valovne dolžine, majhne razsežnosti anomalij, ostre nizkoamplitudne in precej nepravilno oblikovane anomalije, ki so nemara posledica blizu površine ležečih virov, kot so npr. plitvo razmeščene geološke enote ali antropogeni objekti. Eulerjeva dekonvolucijska rešitev nakazuje pretežno valovito podlago $\mathrm{v}$ globinskem razponu od - 500 m do 1000 m. Rezultati Eulerjeve dekonvolucije kažejo, da je relief podlage na proučevanem terenu splošno položen in ploskih oblik.

Ključne besede: aeromagnetika, anomalija, geološka podlaga, podatki, Eulerjeva dekonvolucija, litologija 


\section{Introduction}

Aeromagnetic survey is a powerful tool in delineating the lithology and structure of buried basement terrain. The detailed aeromagnetic map is very effective in cases where the geology of the study area is obviously identified. The purpose of magnetic surveying is to investigate the subsurface based on the variation in the observed magnetic field resulting from the differences in the magnetic properties of the underlying rocks or, in some cases, cultural sources. The geophysical magnetic method is a versatile method and therefore has the advantage of being one of the geophysical prospecting techniques commonly used in exploration programs [1].

This anomalous magnetisation may be associated with the local mineralisation, which is potentially of viable interest, or it could be due to sub-surface structures that have comportment on the location of oil deposits. In general, the magnetic content (susceptibility) of rocks is extremely variable depending on the types of rocks and the environment it is in. To acquire the magnetisation of the earth's magnetic field, there is need to carry out a survey in the area of interest. To achieve this task, the survey can be done on ground or through airborne or waterborne surveys [2]. Early geophysical exploration for iron ore in Nigeria began in the 1960s when the Geological Survey of Nigeria (GSN), with the help of Canadian Air Services Limited, carried out an airborne magnetic survey of some parts of the country.

This study attempts to filter, process and enhance the acquired magnetic data. The resultant data from the airborne magnetic data were further subjected to qualitative and quantitative magnetic interpretation to determine the geometry and depth weighting across the study area using Euler deconvolution.

\section{Description of the study area}

Ilesha and its environs is situated in Osun State, Southwest Nigeria. Ilesha is bounded in the north by Kwara, in the south by Ondo, in the east by Ekiti and partly in the west by Oyo State. The area is located within geographic latitudes $7^{\circ} 30^{\prime}-8^{\circ} 00^{\prime} \mathrm{N}$ and longitudes $4^{\circ} 30^{\prime}-5^{\circ} 00^{\prime} \mathrm{E}$, covering an area of about or approximately $3025 \mathrm{~km}^{2}$. Ilesha lies in the tropical climate zone marked by wet and dry seasons, with an average elevation of $391 \mathrm{~m}$ above sea level. The average daily temperature varies between about $20^{\circ} \mathrm{C}$ for a very cold day to about $35^{\circ} \mathrm{C}$ for a very hot day [3].

\section{Geological settings}

Ilesha is situated within the Nigeria Basement Complex of Southwestern Nigeria. Ilesha and its surroundings lie within the Southwest Nigerian Basement Complex [4]. The formation is a predrift sequence of continental sands, grits and silts (Figure 1). In 1953 and 1957, De Swardt [4] and Russ [5] suggested that the Nigerian basement complex is polycyclic. In 1966 and 1970, Hurley $[6,7]$ confirmed the age of the rocks by using radiometric method. The major rocks associated with Ilesha and its environs form part of the Proterozoic schist belts in Nigeria. The geology of Ilesha and its environs consists of Precambrian rocks that are typical for the basement complex of Nigeria [8]. Regarding the structural features, lithology and mineralisation, the schist belts of Nigeria show considerable similarities to the Archaean greenstone belts $[8,9]$. The base map of Ilesha is shown in Figure 2.

\section{Methodology}

\section{Data acquisition}

The high resolution airborne survey was conducted in two phases. Airborne survey of Southwest Nigeria was completed in August 2009, and all the geophysical work, including data acquisition, was carried out by Furgo Airborne Survey Limited, USA. The airborne magnetic data were obtained using a proton precession with resolution of $0.1 \mathrm{nT}$. The data were obtained at $80 \mathrm{~m}$ altitude along a series of NE-SW planes, with a flight line spacing of $500 \mathrm{~m}$ and tie line spacing of $5000 \mathrm{~m}$. The flight line direction was in the direction 135 azimuths, while the tie line direction was in 45 azimuths. The average magnetic inclination, magnetic declination and magnetic field strength across the 


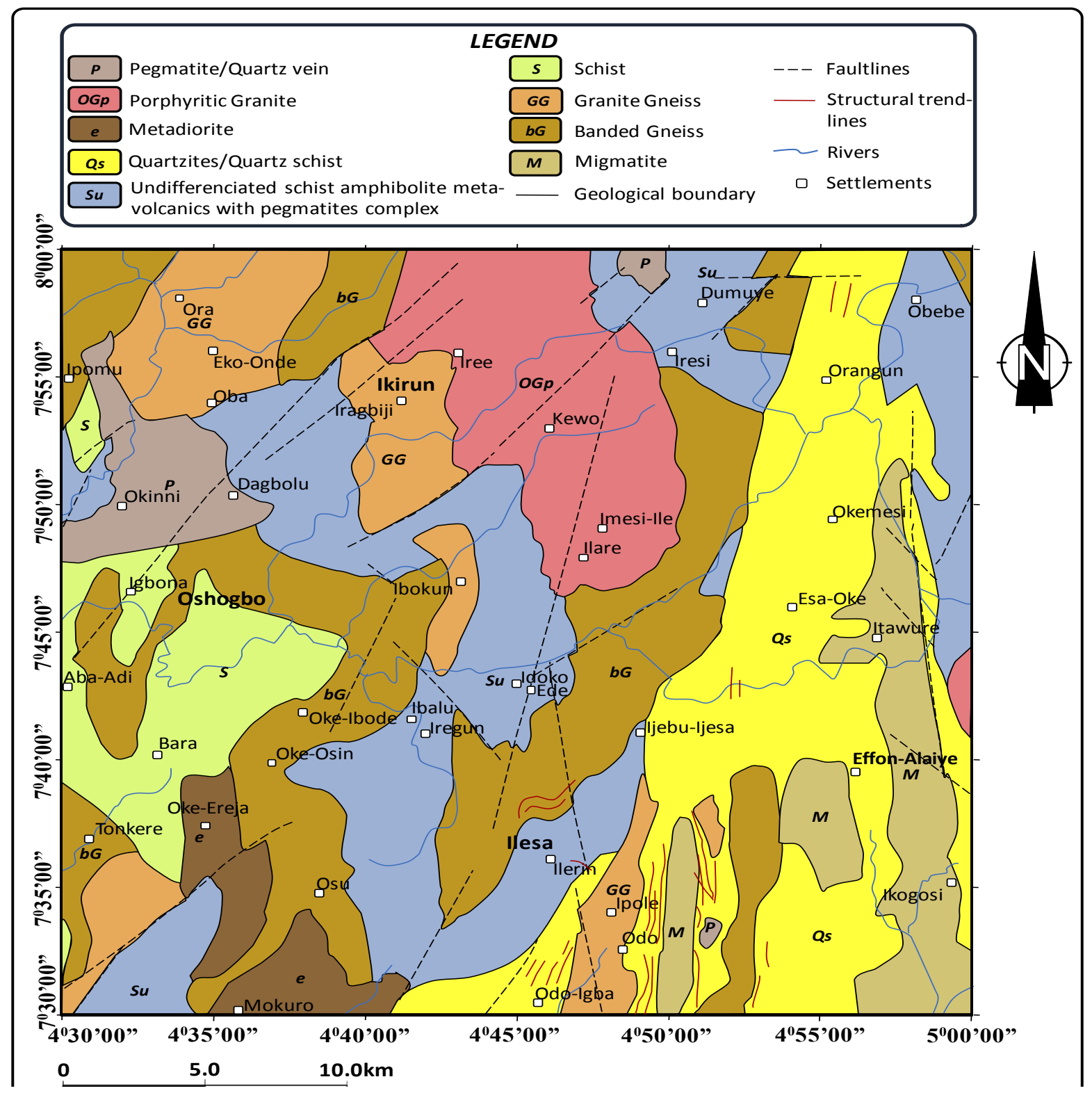

Figure 1: Geological map of llesha and its environs.

survey were $14.02^{\circ}, 3.83^{\circ}$ and $32446.006 \mathrm{nT}$, respectively. The geomagnetic gradient was removed from the data using the International Geomagnetic Reference Field (IGRF) epoch of 2008. The map of the study area is published on a scale of 1:10000 (i.e. $1 \mathrm{~cm}=1 \mathrm{~km}$ on ground). The topographical detail of the map was based on 1:100000 topographical series of Federal Surveys of Nigeria.

\section{Magnetic data processing}

The processing of the magnetic anomalies is based on the analysis of the computer digitised information using the minimum curvature grid- ding method at different altitudinal levels from the compiled total magnetic intensity of the study area, as shown in Figure 3. The gridding method fits minimum curvature curves to the data points as well as producing visually alluring maps from irregularly spaced data and attempts to express trends suggested in the data using methods described by Briggs [10].

\section{Data filtering}

The area under consideration is made up of Basement Complex thus, the interest was to remove the cultural effect and enhance the short-wavelength signal emanating from shal- 


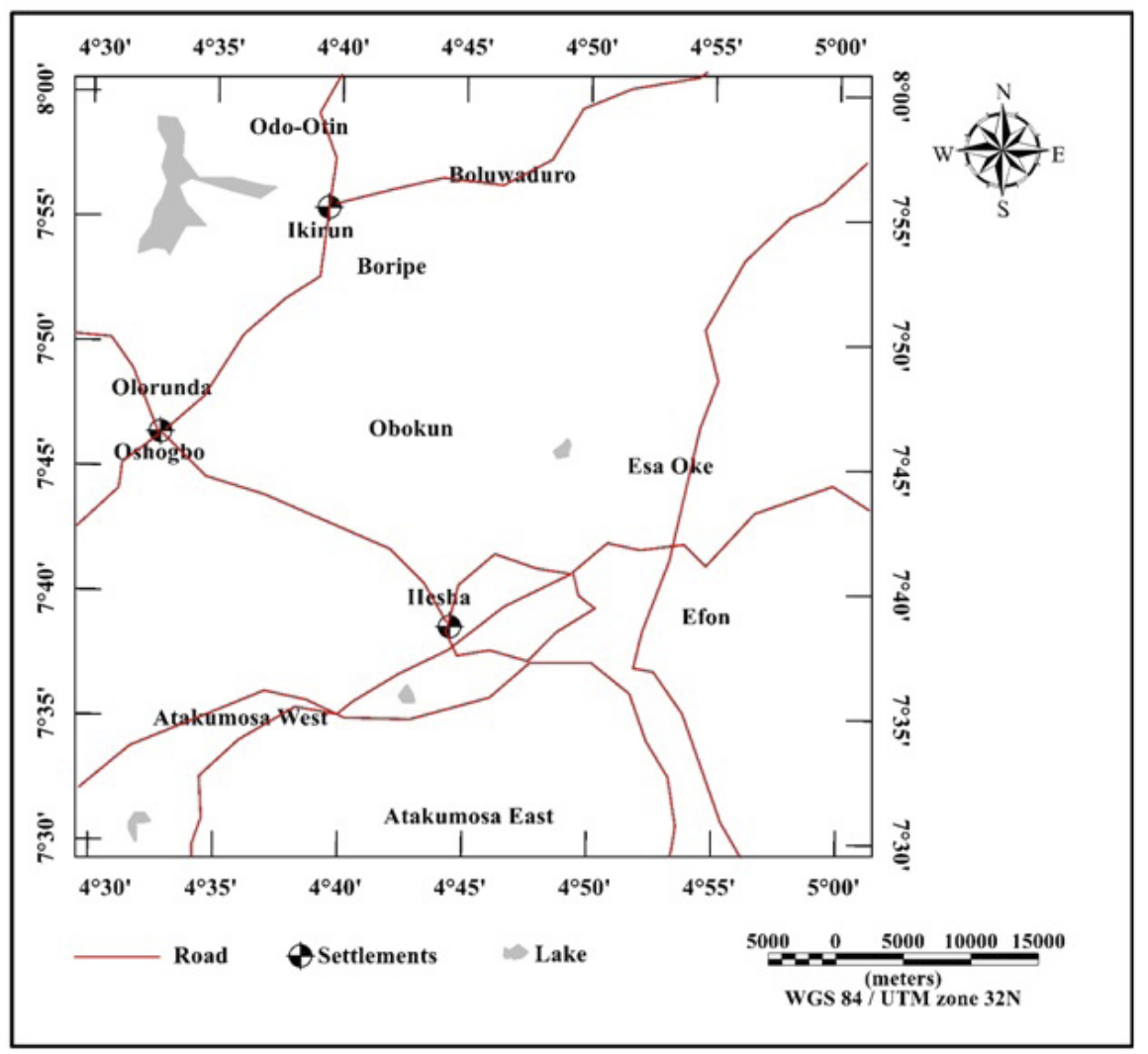

Figure 2: Base map of llesha and its environs.

low geological features. Digitised aeromagnetic data were prepared to improve its quality for better understanding of the sub-surface geology of the deposit by filtering operation $[11,12]$. The desired improvements in the quality of the aeromagnetic data were achieved by the application of two-dimensional fast Fourier transform filtering technique.

\section{Interpretational techniques}

\section{Reduced-to-equator (RTE) map}

Abeokuta and its environs are situated below magnetic equator and since Earth's magnetic field intensity decreases from the poles to the equator, peaks of magnetic anomalies are wrongly positioned over their sources as well as skewed along a particular direction. This makes interpretation of magnetic anomalies complex. However, at low magnetic latitude, Luo et al. [13] proposed special reduction to equator, which transforms the observed magnetic anomaly at the equator into an anomaly that would have been measured if the magne- tisation and ambient field were both vertical. This operation transforms theoretical magnetic anomalies located at the pole and magnetised by induction only into the observed magnetic anomalies.

The desired improvements in the quality of the aeromagnetic data were achieved by the application of two-dimensional fast Fourier transform technique. In 2010, Luo et al. [13] assumed the set of observed magnetic data acquired on planar observation surface. Earlier work done by Gun [14] was adopted, where reduction-to-pole operation in wave number domain was performed, given as Equation 1:

$$
A_{T}(u, v)=\frac{A_{o(u, v)}}{(\sin I+i \cos I \cos I \cos (D-\theta))^{2}}
$$

where $I$ and $D$ are the inclination and declination of the core field; $(u, v)$ is the wave number corresponding to the $(x, y)$ directions, respec-

tively; $\theta=\tan ^{-1}\left(\frac{u}{v}\right) ;$ and $i^{2}=1$. Taking horizontal magnetisation into consideration, $I=0$ and 
$D-\theta$ is close to \pm 90 , which makes the imaginary part close to zero; thus, reduction-to-pole processing will be unstable at low latitudes and singular at the equator. To overcome this complexity, Fourier transform of the observed magnetic field is given as Equation 2:

$A_{0}(u, v)=A_{T}(u, v)$

$(\sin I+i \cos I \cos I \cos (D-\theta))^{2}$

According to Luo et al. [13], application of inverse Fourier transform to Equation 2 gives Equation 3:

$\left.F^{-1} A_{o r}(u, v)\right]=\left[A_{T}(u, v)\right.$

$\left.(\sin I+i \cos I \cos I \cos (D-\theta))^{2}\right]$

\section{Euler deconvolution}

Euler deconvolution is a method to estimate the depth of Subsurface magnetic anomalies and can be applied to any homogeneous field, such as the analytical signal of magnetic data. It is particularly good at delineating the subsurface contacts. It has been observed that the depth estimates from magnetic data are more accurate if the pole-reduced magnetic field is used, than when using the magnetic data themselves. Euler deconvolution was originally developed in exploration geophysics for rapidly estimating the location of and depth to magnetic or gravity sources. It is based on the fact that the potential field produced by many simple sources obeys Euler's homogeneity equation [15]. If a given component of the magnetic anomalous field $\Delta T(x, y, z)$ satisfies the following equation:

$$
\Delta T(x, y, z)=\mathrm{t}^{\mathrm{n}} \Delta T(x, y, z)
$$

where $n$ is the degree of homogeneity, then differentiating Equation 4 with respect to $t$ gives Equation 5:

$$
x \frac{\partial \Delta T}{\partial x}+y \frac{\partial \Delta T}{\partial y}+z \frac{\partial \Delta T}{\partial z}=n \Delta T
$$

where $x, y$, and $z$ are the coordinates of the field observation points and assumed to be at the origin. Considering the potential field data, Euler's equation can be stated as in Equation 6, according to Thompson [16]:

$$
\begin{aligned}
& \left(x .-x_{0}\right) \frac{\partial T}{\partial x}+\left(y-y_{0}\right) \frac{\partial T}{\partial y}+ \\
& +\left(z-z_{0}\right) \frac{\partial T}{\partial z}=N(B-T)
\end{aligned}
$$

where $\left(x_{0}, y_{0}, z_{0}\right)$ is the position of a magnetic source whose total magnetic field $T$ is measured at $(x, y, z)$. The total field has a regional value $B$, and $N$ is the degree of homogeneity (structural index), which is equivalent to $n$ in Equation 5 . $N$ is an exponential factor that corresponds to the rate at which the field falls off with distance for a source of given geometry. Processed data were subjected to Euler deconvolution operation to determine the depth to the magnetic source [16-21]. In 2011, Silva and Barbosa [22] proposed Euler deconvolution as a useful tool to calculate approximately the localities of various geologic bodies. However, this structure leads to a large number of Euler solutions. This situation is further complicated when the geometry of the source is unidentified and when several sources with diverse geometries are present. Therefore, the geometry of the source (allied to the structural index) is tentatively assumed by the interpreter, and the Euler deconvolution is applied to whole dataset. Hence, for each presumed structural index, Euler deconvolution produces a map of source-position estimates. This technique leads to a set of maps, each one revealing an expansive cloud of Euler solutions, rendering nontrivial the interpretation of the localities of various geologic bodies. In concurrence with earlier research by Melo et al. [21] as well as Silva and Barbosa [22], the large number of evaluated solutions by Euler deconvolution still remains an operational weakness of this method. To reduce this difficulty, some methods have been developed to select the best Euler solutions and to reduce the number of accepted Euler solutions. 


\section{Result and discussion}

The total magnetic intensity map of Ilesha and its environs is shown in Figure 3. Total magnetic intensity value of the field ranged from -77.7 to $139.7 \mathrm{nT}$. Total magnetic field intensity map indicates high-magnitude magnetic intensity values in the north, east, parts of the west, and the central part of the mapped area. Regions of magnetic lows (low-amplitude magnetic anomaly) and highs (high-amplitude anomaly) are apparent on the magnetic map. The defined magnetic highs and lows as visible on the map are in the real sense relative. The northeastern part of the study area is characterised with high intensity, which is related to the lithological variation in the basement. The sharp contrast is enhanced due to the sharp magnetic intensity contrast between the magnetic susceptibilities of the crystalline and the sedimentary rocks. The RTE map (Figure 4) shows that the asymmetries of the observed anomalies had been corrected and minimised, and the correction centres the anomalies directly over the causative elongated bodies. The RTE magnetic intensity values range from $-74.8 \mathrm{nT}$ to $130 \mathrm{nT}$. The RTE map is characterised by high frequencies, short wavelengths, small size, weak intensity, sharp low amplitude and nearly irregular-shaped anomalies, which may due to near-surface sources, such as shallow geologic units and cultural features.

The area under study shows variation in the magnetic field of the earth. This variation is because of local changes in the geological properties of underlying sub-surface of the study area. The variation also reflects the presence of considerable amounts of magnetic bodies in the area. The northern region of the total magnetic intensity map is characterised by high magnetic values, which correspond with porphyritic granite; banded gneiss and undifferentiated schist amphibolite, while the southern section with low magnetic intensity corresponds to metadiorite and quartzite. The processed high-resolution airborne magnetic data, which have been reduced to equator, were subjected to Euler's deconvolution operation to determine depth to magnetic source [16-19]. Figures 5-8 show the maps (magnetic gradients) of the $x, y, z$ derivative grids of the RTE magnetic intensity data and the Euler map of the study area, respectively. These magnetic gradient maps are required for the calculation of the analytical signal magnitude grids (map) shown in Figure 9, which is needed to perform the located Euler deconvolution adopted to achieve the aim of this study.

The standard and located Euler deconvolution methods were used to examine all grid locations in order to retain only those locations with valid solution using structural indices $0,1,2$ and 3 , and the results are presented in Figures 10-13, respectively. The centre of the plotted circles represents the plan location $\left(x_{0}\right.$ and $\left.y_{0}\right)$ of the interpreted source, and the diameter is the depth estimator (i.e. depth is proportional to diameter). In addition, the depths are displayed using colour variation to represent different ranges.

The analytic signal map of Ilesha (Figure 9) was derived from the analytic signal grid computed from the first-order vertical derivative values of two horizontal gradients and one vertical gradient of the total magnetic intensity after reduction to equator of the study area $[16,17]$. The analytic signal map of the study area shows the amplitudes of the magnetic signature. Prominent high amplitude analytic signal anomalies are apparent on the analytic signal map. The analytic function acts as the envelope of possible phase shift of the observed anomaly and peaks over magnetic contacts. The analytic signal map also shows the attenuation of shallow sources. Some regions in the map are characterised by very high amplitude, which reflects lithological variation in the magnetic basement, while some parts of the study area are dominated by low amplitude and indicate the presence of thick sediment covering the weathered basement. The magnitude of the amplitude of magnetic gradient intensity ranges from 0.0077 to $0.2501 \mathrm{nT} / \mathrm{km}$. The Euler solution was applied in determining the depth to the magnetic sources in the survey area by setting an appropriate structural index (SI). A total of 25675 solution points were obtained. Results with the tightest cluster around recognised sources are likely to give the best solutions and are therefore accepted. On the other hand, the obtained solutions were windowed with respect to their Euler SI (ESI) to select the 


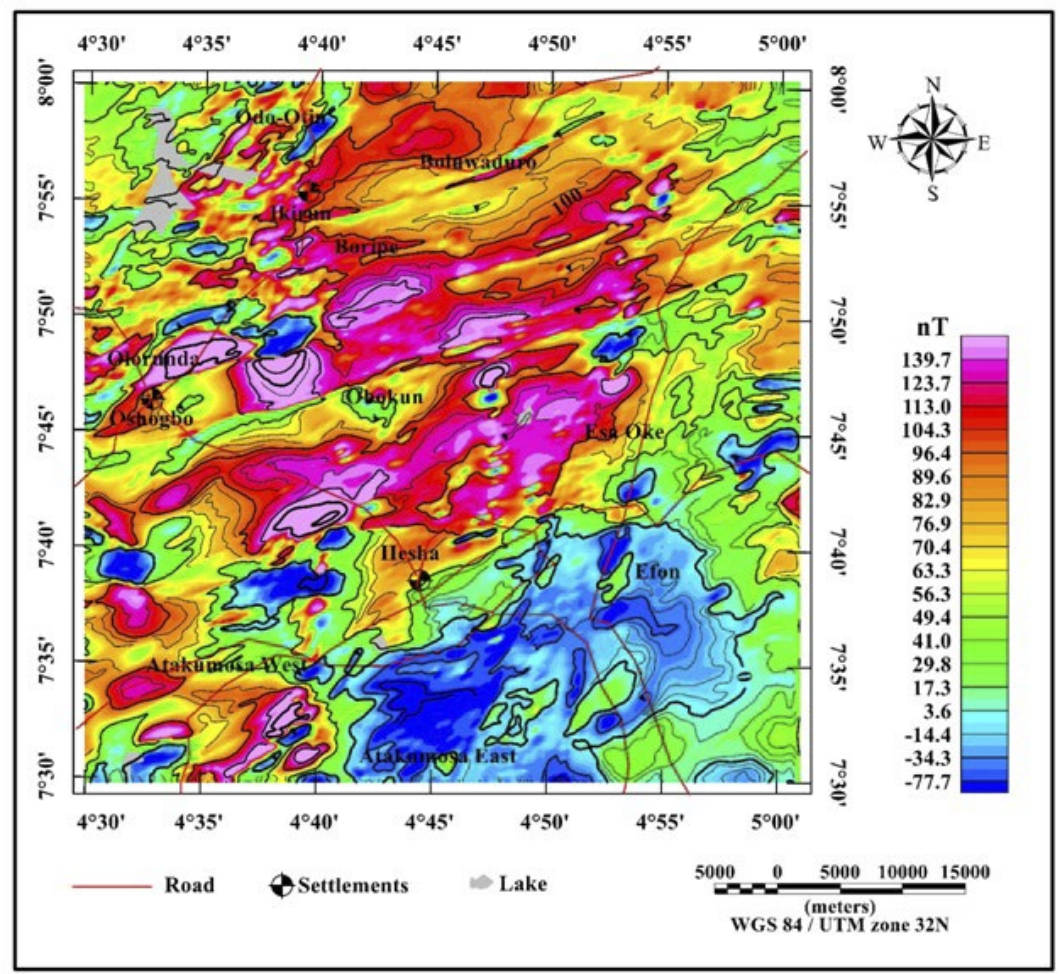

Figure 3: Total magnetic intensity map of llesha and its environs.

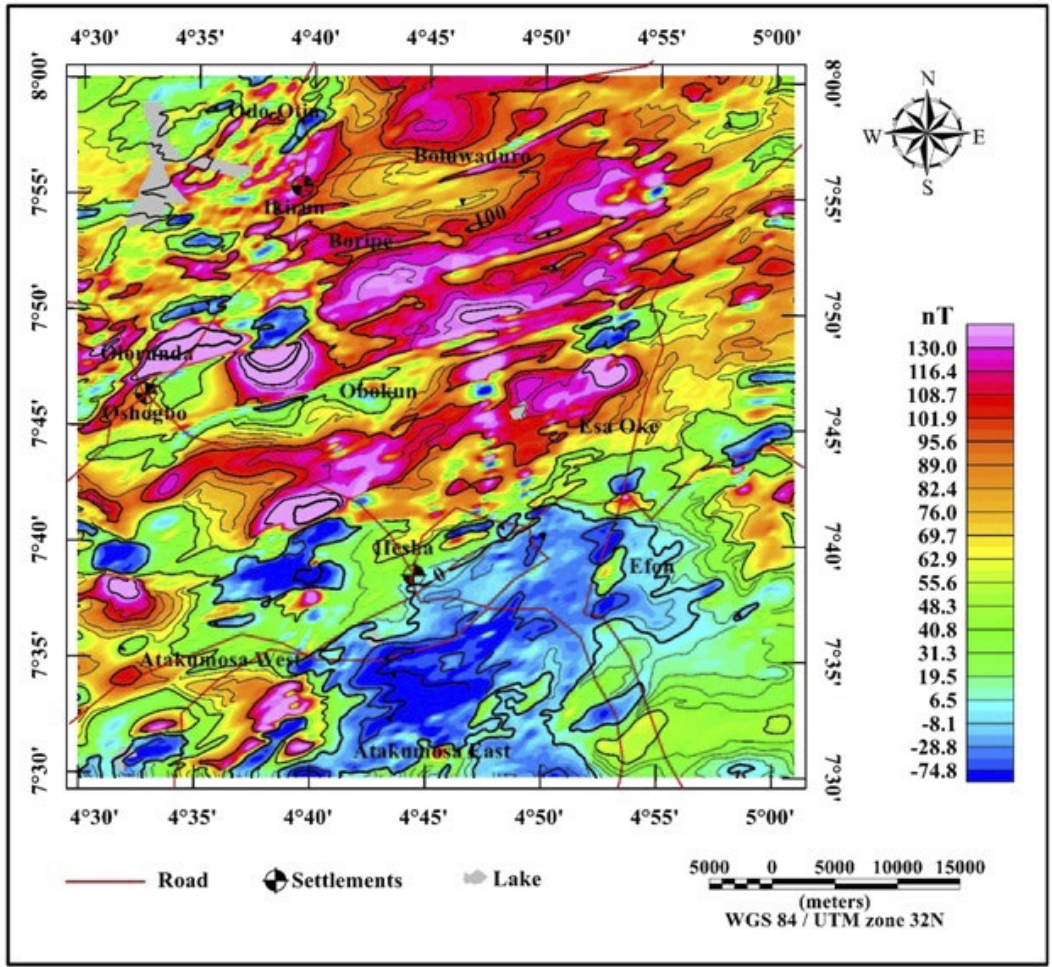

Figure 4: Total magnetic intensity map of llesha after reduction to the equator. 


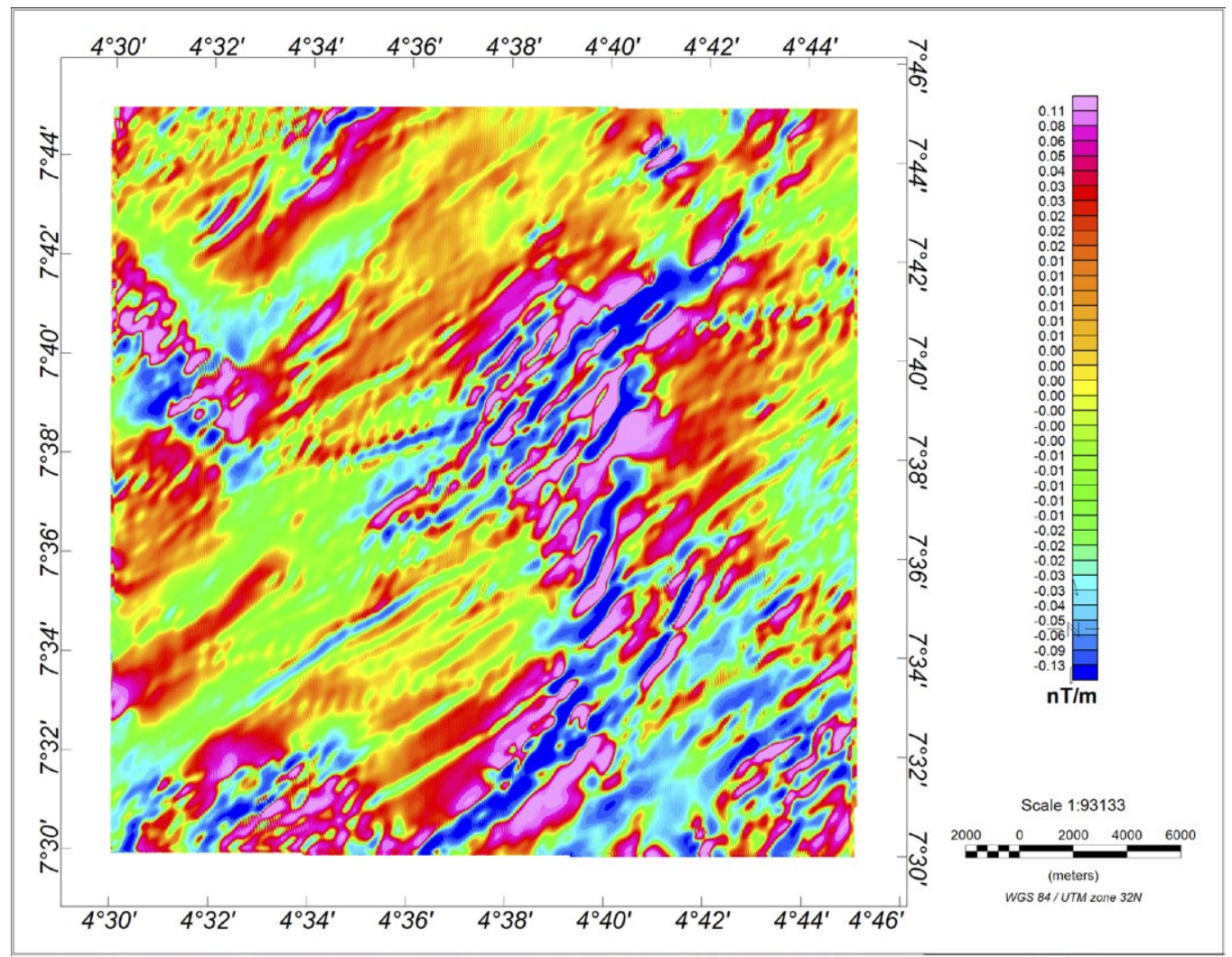

Figure 5: Gradient grid along x-direction of reduced-to-equator magnetic intensity data of Ilesha.

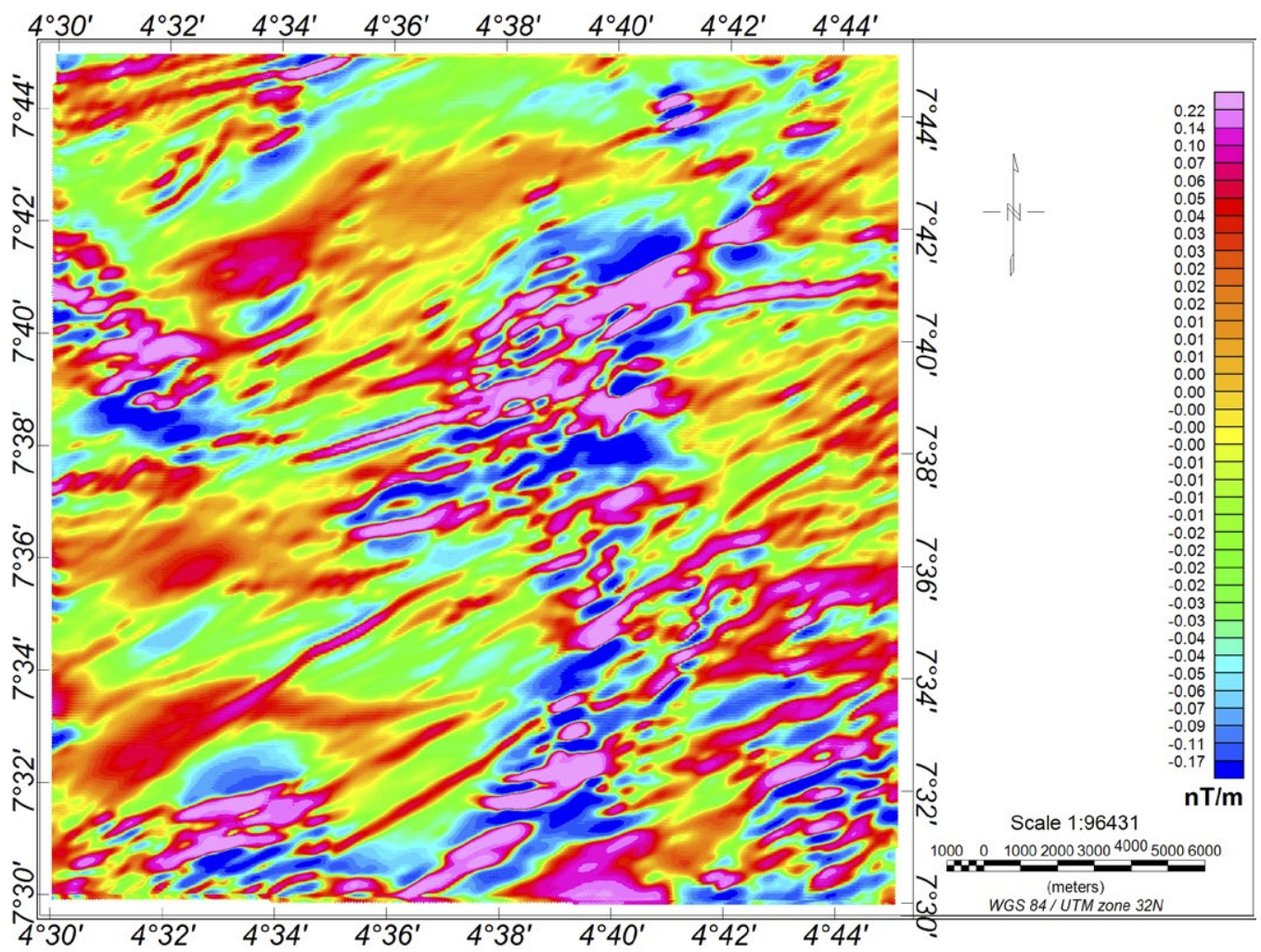

Figure 6: Gradient grid along y-direction of reduced-to-equator magnetic intensity data of llesha. 


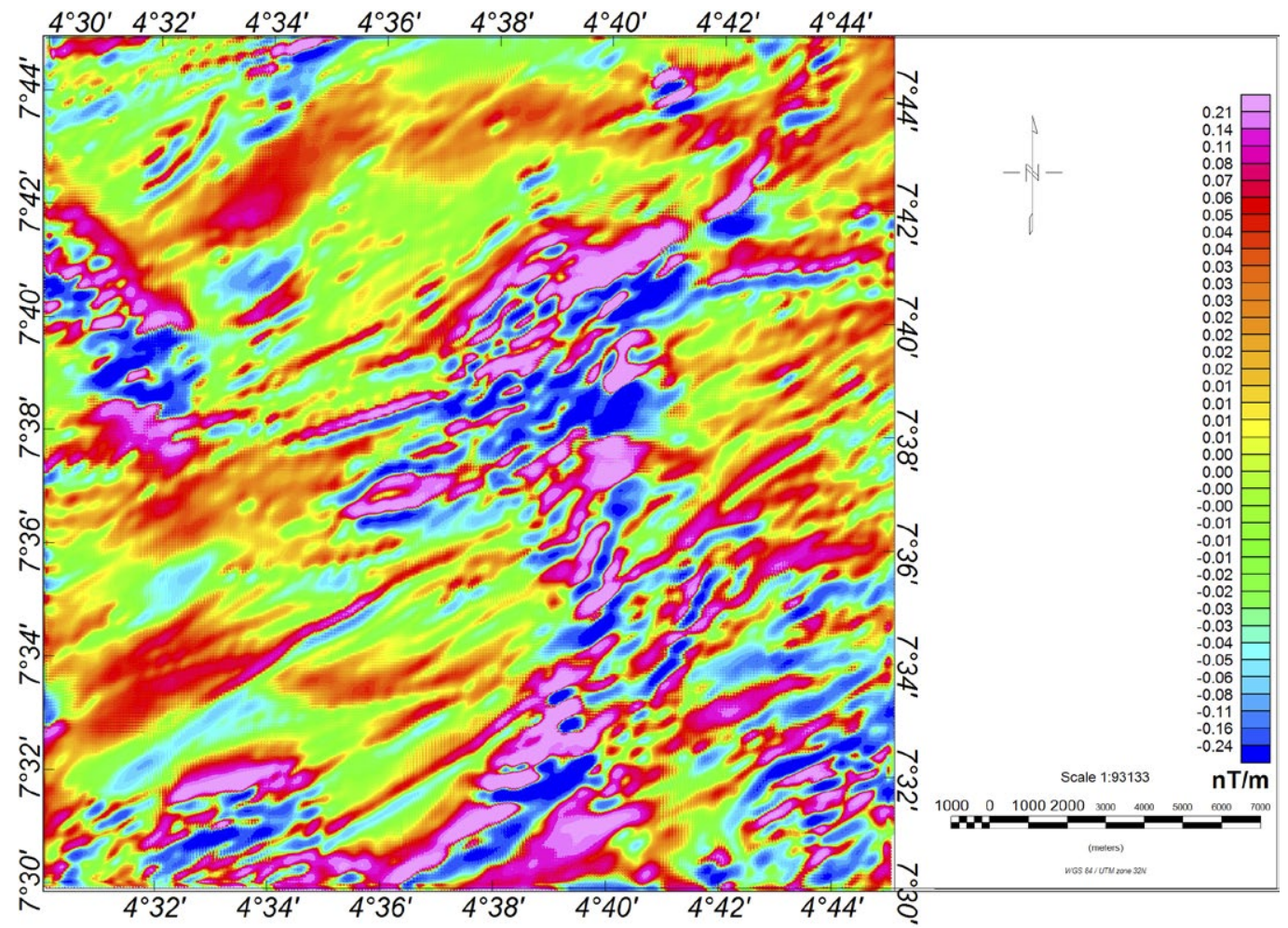

Figure 7: Gradient grid along z-direction of reduced-to-equator magnetic intensity data of llesha.

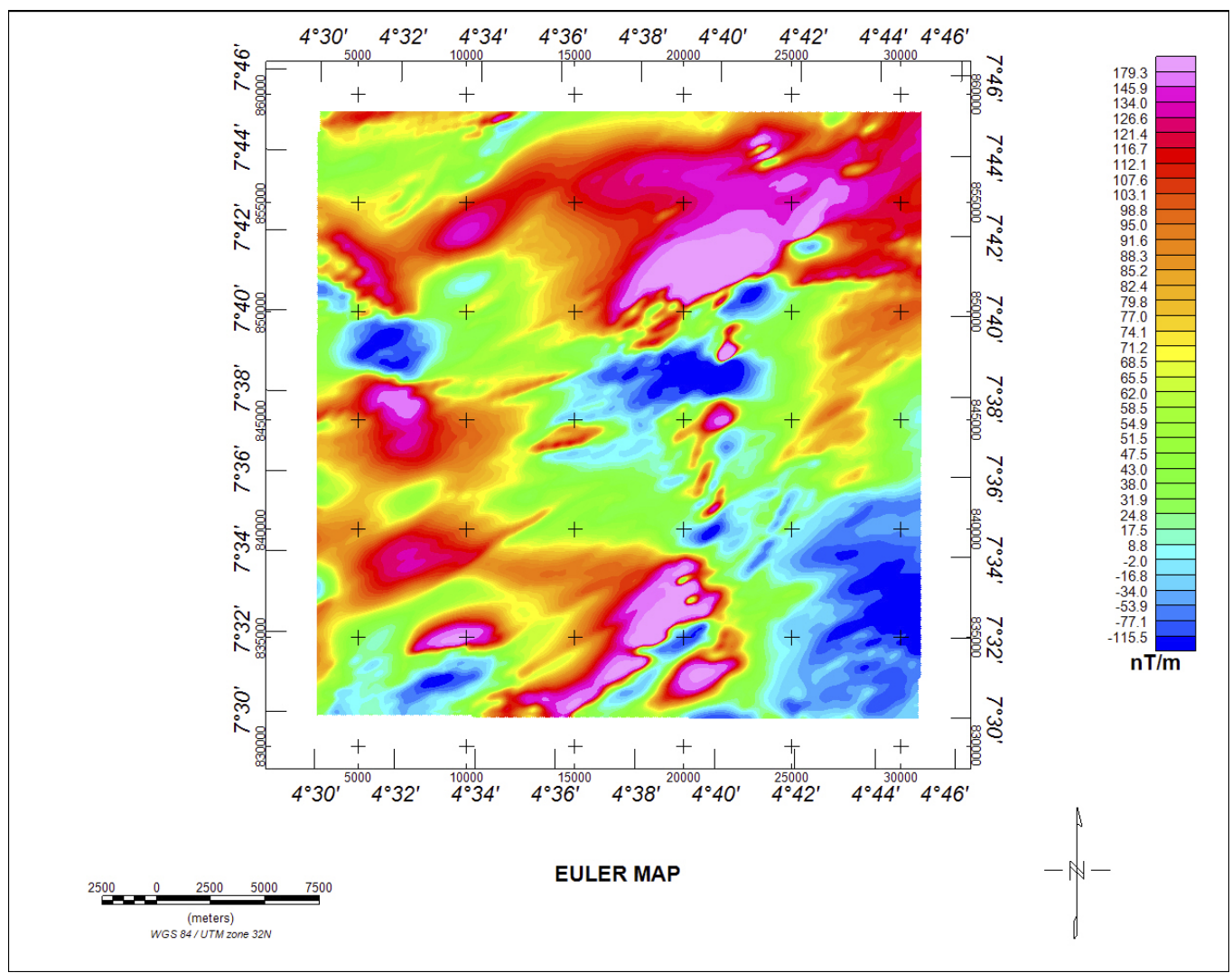

Figure 8: Euler map of llesha and its environs. 


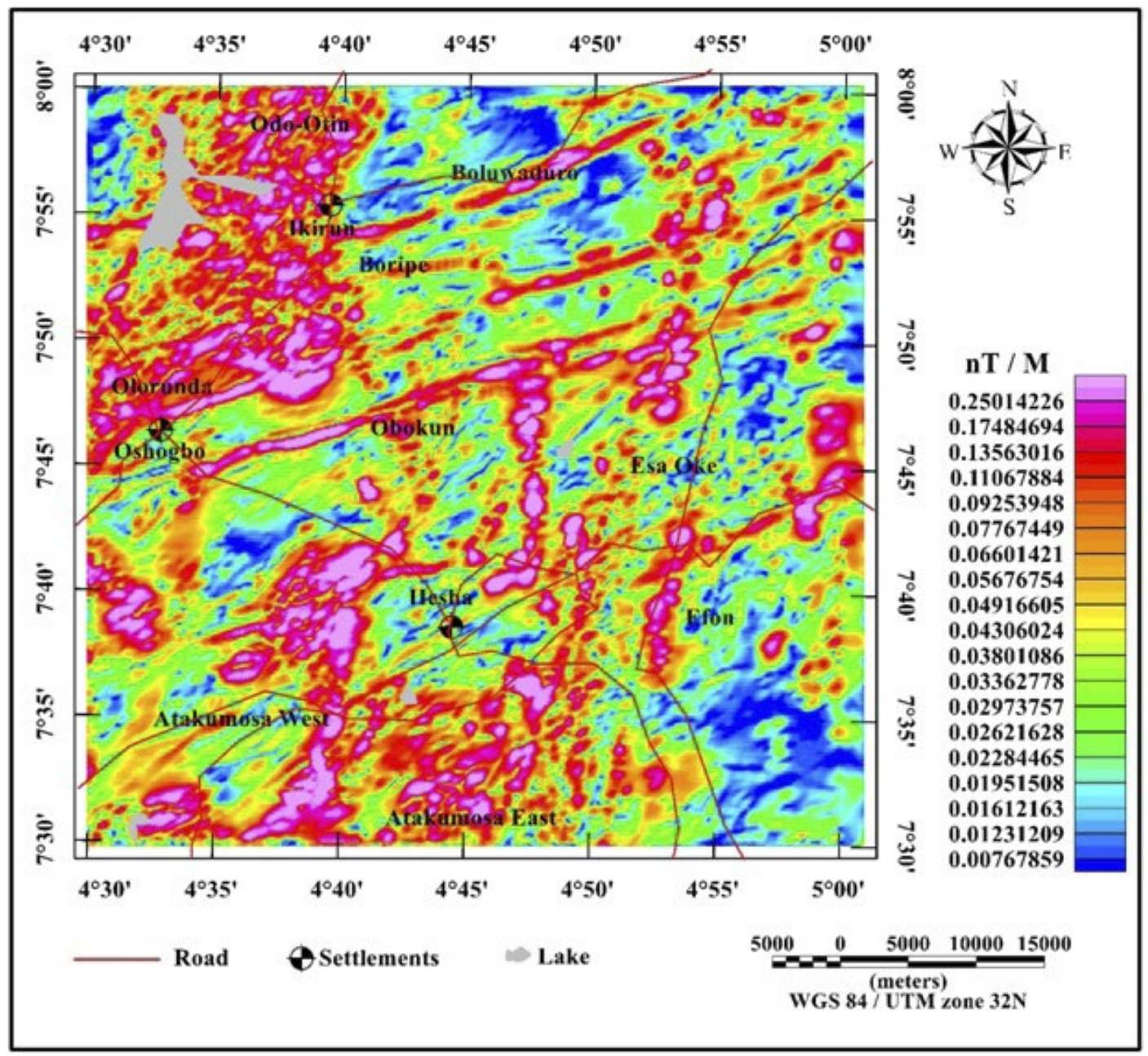

Figure 9: Analytic signal of RTE map of llesha and its environs.

most accurate results in relation to the geological formation of the area under consideration. These solutions were obtained for varying SI values of $0-3$, with an average error in depth estimation that was less than the required maximum 11\% tolerance; the window size is presented in Table 1. It was detected that for $\mathrm{SI}=1$, $\mathrm{SI}=2$ and $\mathrm{SI}=3$, the dyke/sill, dyke/horizontal cylinder and sphere models were the best fits, which are in good agreement with the geological formation (pure basement complex) of Ilesha and its environs. The solution produced realistic results that were consistent with the type of geologic model of the study area.

The windowed Euler deconvolution solution points, on varying the ESIs, coincide weakly with regions having high analytic signal amplitude and, therefore, are likely to represent regions with meaningful anomalies and they are in dykes and spheres. Euler depth gave useful information about the subsurface topography of the basement complex. The windowed Euler depth solution has colour-coded circles; the circle's colours indicate the depth range and the size defines the depth variation within the range from -500 to $1000 \mathrm{~m}$.

The centre of the plotted circles represents the plan location $\left(x_{0}\right.$ and $\left.y_{0}\right)$ of the interpreted source, and the diameter is the depth estimator, i.e. depth is proportional to diameter. In addition, the depths are displayed using colour variation to represent different ranges. Figures 10-13 show the windowed Euler depth solutions as colour-coded circles; the circle's colours indicate the depth range, and the size defines the depth variation within the range. The Euler solutions show notable anomalies in the Boluwaduro, Obokun and Boripe areas within 


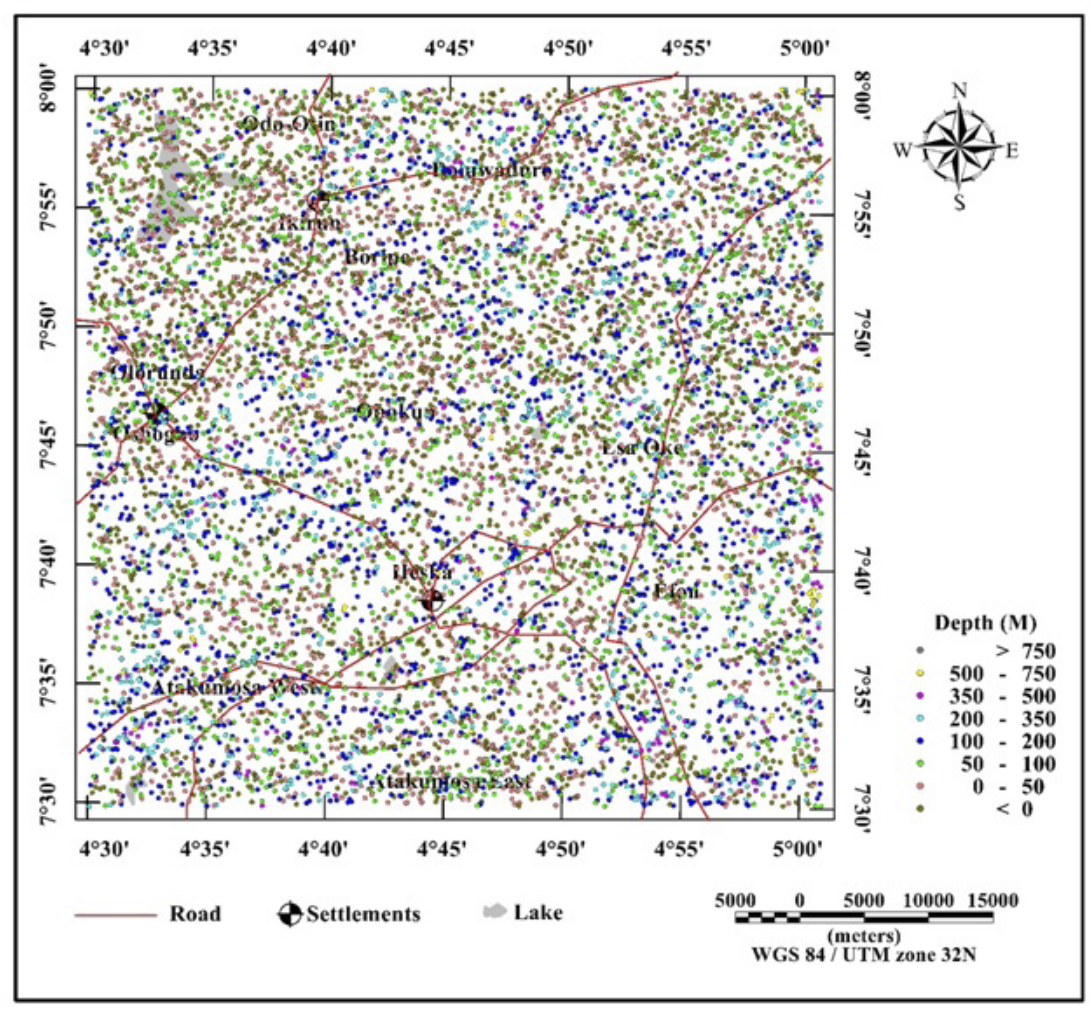

Figure 10: Classified map of Euler deconvolution calculated from the RTE magnetic map of the studied area (structural index $[S I]=0$ ).

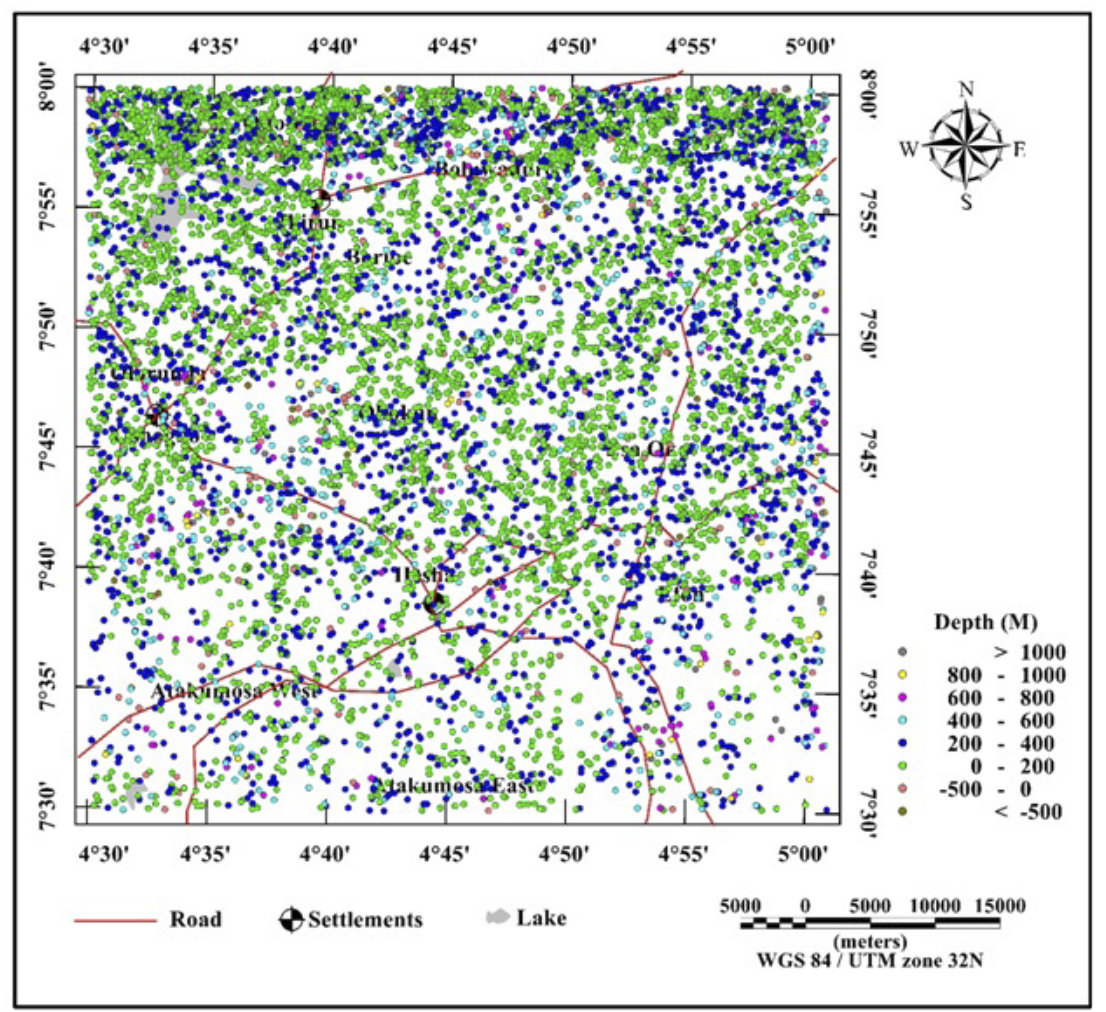

Figure 11: Classified map of Euler deconvolution calculated from the RTE magnetic map of the studied area (structural index $[S I]=1$ ). 


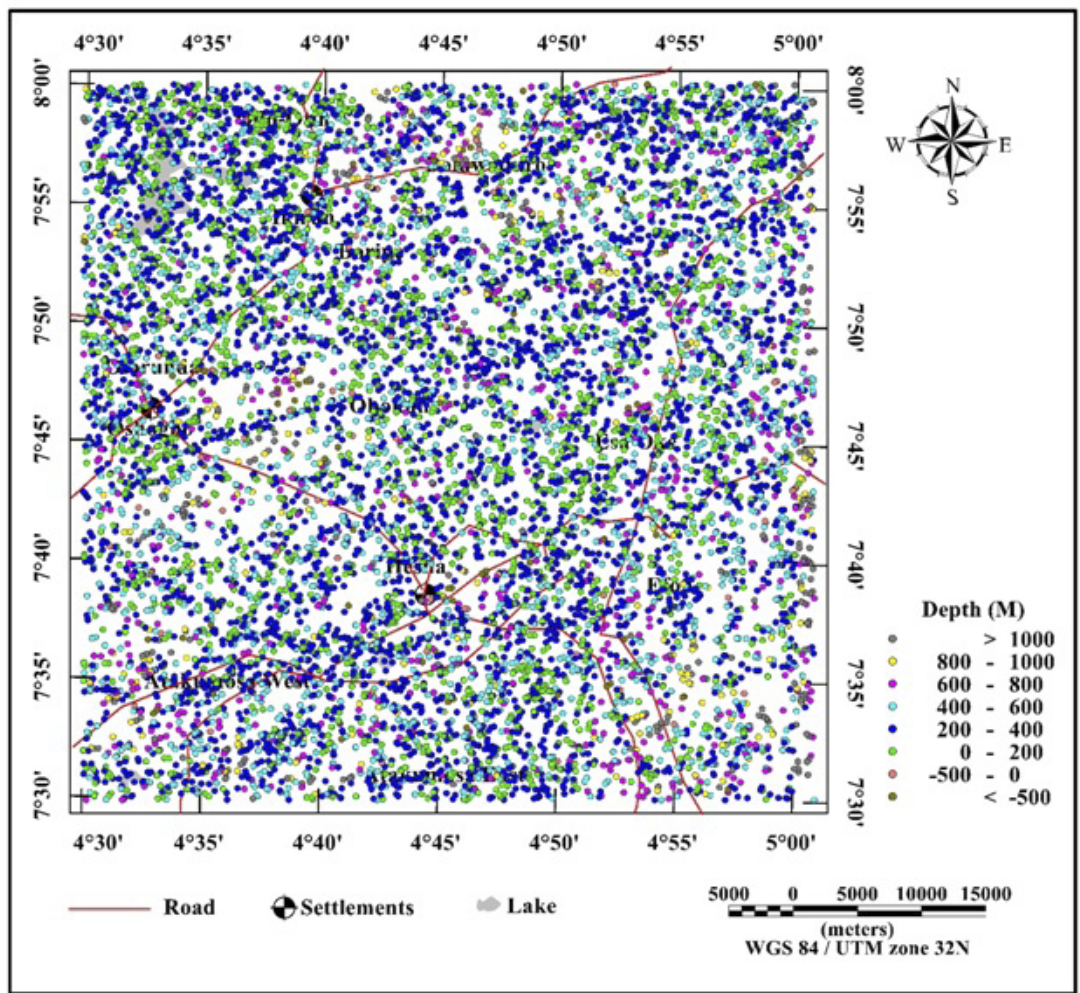

Figure 12: Classified map of Euler deconvolution calculated from the RTE magnetic map of Ilesha and its environs (structural index $[S I]=2$ ).

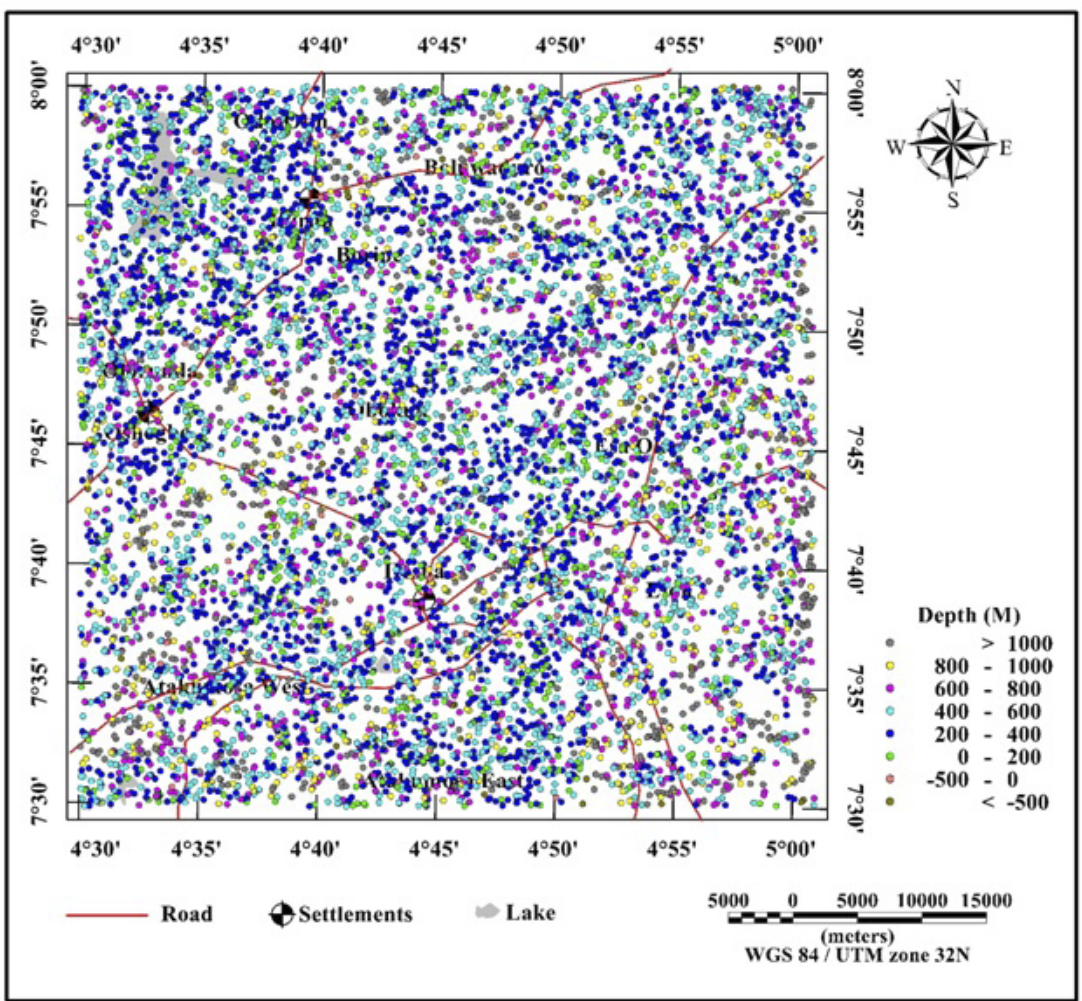

Figure 13: Classified map of Euler deconvolution calculated from the RTE magnetic map of the studied area (structural index $[S I]=3$ ). 
Table 1: Result of depth to magnetic basement from standard Euler solution method

\begin{tabular}{ccccc}
$\begin{array}{c}\text { Sample } \\
\text { number }\end{array}$ & $\begin{array}{c}\text { Structural } \\
\text { index }\end{array}$ & Geological model & $\begin{array}{c}\text { Number of finite } \\
\text { solutions }\end{array}$ & Depth \\
\hline 1 & 0 & Contact & $3(x, y$ and $z)$ & $<0$ to $>750$ \\
\hline 2 & 1 & Dyke/sill & $\begin{array}{c}2(x \text { and } y) / \\
2(z \text { and } x \text { or } y)\end{array}$ & $<-500$ to $>1000$ \\
\hline 3 & 2 & $\begin{array}{c}\text { Dike/horizontal } \\
\text { cylinder }\end{array}$ & $1(x$ or $y) /(z)$ & $<-500$ to $>1000$ \\
\hline 4 & 3 & Sphere & 0 & $<-500$ to $>1000$ \\
\hline
\end{tabular}

the area under consideration. The solutions obtained for operating Euler deconvolution on the analytical grid of the RTE the magnetic intensity of Ilesha and its environs are presented in Table 1. In Figure 10, the depth of the basement ranges between zero and $>750 \mathrm{~m}$, while in Figures 11-13, the depths range from $<-500 \mathrm{~m}$ to $<1000 \mathrm{~m}$. The plotted depth solutions were referenced to the Ilesha data in Nigeria and therefore represent the depth values above and below mean sea level. The Euler solution recognised the solutions for regions with magnetic sources located above the Ilesha reference datum and for regions with magnetic sources located below the reference datum. These regions coincide with the positive (magnetic highs) and negative (magnetic lows) anomaly points within the area under consideration, respectively. The resulting Euler depth range of $0-50 \mathrm{~m}$ coincides with the region where the basement rocks crop out on the surface, while the depth range between 0 and $-200 \mathrm{~m}$ correspond to the part of the study area where the basement rocks are overlain by thick sediment layer. The Euler solution for Ilesha and its environs reveals relatively deep basement source, $>55 \mathrm{~m}$ in depth, which progressively becomes shallower in the north-south direction. Communities such as Boripe, Obokun, Boluwaduro, Odo-otin and Ikirun correspond to the part of the region where the reference datum is greater than zero. The linear clustering circles are suggested to be the result of faults and/or contacts with depth values ranging between 0 and $1000 \mathrm{~m}$. These solutions are trending in the NE-SW, E-W, NNW-SSE, NW-SE, ENE-WSW directions within Ilesha and environs.

\section{Conclusion}

The study was carried out using the digitised high-resolution magnetic data of Ilesha, Southwestern Nigeria, to estimate the depth of magnetic sources and to map the location of anomalies. The data were analysed using suitable magnetic filtering and gradient techniques. Analysis of this processed airborne magnetic data provides appreciable geological information about Ilesha and its environs. The study identified a relatively high magnitude of positive magnetic intensity values, ranging from 17.3 to $139.7 \mathrm{nT}$, which characterised the north-western, the north and the southern parts of Ilesha in Southwest Nigeria. These regions reflect the lithological variation in igneous rocks with sedimentary section and are composed of narrow, closely spaced, short-wavelength and high-frequency anomalies, which correspond to shallow basement and basement complex terrain. In addition, low-magnitude magnetic intensity values ranged between -77.7 and $3.6 \mathrm{nT}$, which is characteristic of the south-west part of the area under consideration. This region has smooth, broad and long-wavelength anomalies corresponding to deep basement and related to sedimentary magnetisation contrast.

Total magnetic intensity after RTE mapping ranged from 74.8 to $130.0 \mathrm{nT}$. The reduction to equator filter operation rightly corrected the asymmetries in the observed anomalies, which were minimised, and centred the anomalies directly over the causative elongated bodies. The study area was dominated by positively strong magnetic intensity corresponding to southwest Basement Complex of Nigeria. The flight 
altitude to the top of the magnetic basement obtained using Euler deconvolution ranged from a mean value of -500 to $1000 \mathrm{~m}$. The result with the tightest cluster around recognised sources is likely to give the best and acceptable solution. These solutions were obtained by varying the SI values of $0,1,2$ and 3 with an average error in depth estimation less than the required maximum $11 \%$ tolerance and window size. This study revealed that for $\mathrm{SI}=1, \mathrm{SI}=2$ and $\mathrm{SI}=3$, the dyke/sill, dyke/horizontal cylinder and sphere models were the best fits, which are in good agreement with the geological formation (pure basement complex) of Ilesha and its environs.

The results of the Euler deconvolution also reveal that crystalline basement is relatively flat and shallow as the rocks exit closer to the ground surface within the basement complex terrain. The results obtained from analysis and interpretation of aeromagnetic data of Ilesha and its environs provide salient information about the crystalline rock transition from the basement complex terrain.

\section{References}

[1] Milson, J. (2003): Field Geophysics. England: John Wiley \& Sons, $249 \mathrm{p}$.

[2] Reeves, C. (2007): Aeromagnetic Surveys: principle, practice and interpretation. Geosoft INC, $155 \mathrm{p}$.

[3] Badejo, A.O., Adekunle, A.A, Oyerinde, A.O. (2013): Pollution studies on groundwater contamination: water quality of Abeokuta, Ogun State, Southwest Nigeria. Journal of Environment and Earth Sciences, 3, pp. 162-166.

[4] De Swardt, A.J. (1953): The geology of the country around Ilesha. Geological Survey of Nigeria Bulletin, 23, $55 \mathrm{p}$

[5] Russ, P. (1957): Airborne electromagnetics in review. Geophysics, 22, pp. 691-713.

[6] Hurley, S. (1966): Electromagnetic reflections in salt deposits. Journal of Geophysics, 32, pp. 633-637.

[7] Hurley, S. (1970): Radar propagation in rock salt. Geophysical Prospecting, 18, pp. 312-328.

[8] Rahaman, M.A. (1976): A review of the basement geology of Nigeria in kogbe. Geology of Nigeria Elizabeth publishing CO, pp. 41-58.
[9] Ajayi, T.R. (1981): On the geochemistry and origin of the amphibolites of Ife Ilesha area South West Nigeria. Journal of Mining and Geology, 17, pp. 179-196.

[10] Briggs, I. (1974): Machine contouring using minimum curvature. Geophysics, 39, pp. 39-48.

[11] Hildenbrand, T.G. (1983): A Filtering Program based on two - dimensional Fourier analysis. U.S. Geological Survey, $61 \mathrm{p}$.

[12] Hinze J., et al. (2005): New standards for reducing gravity data: The North American gravity database. Geophysics, 70, pp. 25-32.

[13] Luo, Y., Xue, D., Wang, M. (2010): Reduction to the pole at the equator. Chinese Journal of Geophysics, 53, pp. 1082-1089.

[14] Gun, P. J. (1975): Linear transformation of gravity and magnetic fields. Geophysical Prospecting, 23, pp. 300-312.

[15] Hood, P. (1965): Gradient measurements in aeromagnetic surveying: Geophysics, 30, 891-902.

[16] Thompson, D.T. (1982): EULDPH: a new technique for making computer-assisted depth estimates from magnetic data. Geophysics, 47, pp. 31-37.

[17] Reid, A.B., Allsop, J.M., Ganser, H., Millett, A.J., Somerton, I.W. (1990): Magnetic Interpretation in three dimensions using Euler deconvolution. Geophysics, 55, 80-91.

[18] Hsu, K.S., Coppens, D., Shyu, C.T. (2002): Depth to magnetic source using the generalized analytical signal. Geophysics, 63, pp. 194-1957.

[19] Mushayandebvu, M.F., Driel, V., Reid, A.B., Fairhead, J.D. (2001): Magnetic source parameters of 2D structures using extended Euler deconvolution. Geophysics, 66, pp. 814-823.

[20] Stavrev, P., Reid, A. (2007): Degrees of homogeneity of potential fields and structural indices of Euler deconvolution. Geophysics, 72, 1-12.

[21] Melo, F.F., Barbosa, V.C.F., Uieda, L. Oliveira, V.C., Silva, J.B.C. (2013): Estimating the nature and the horizontal and vertical positions of 3D magnetic sources using Euler deconvolution. Geophysics, 78, 87-98.

[22] Silva, J.B.C., Barbosa, V.C.F. (2003): 3D Euler deconvolution: Theoretical basis for automatically selecting good solutions. Geophysics, 68, pp. 1962-1968. 